\title{
Analisis Perbedaan Kinerja Keuangan Atas Kebijakan POJK 11/P0JK.03/2020 Terhadap Perusahaan di Subsektor Lembaga Keuangan Yang Terdaftar Di Bursa Efek Indonesia Randy Heriyanto1, Fitra Oliyan2
}

heriyantorandy@gmail.com ${ }^{1}$. oliyan.fitra@gmail.com ${ }^{2}$

Jurusan Akuntansi, Politeknik Negeri Padang1

Email:heriyantorandy@gmail.com

Jurusan Akuntansi, Politeknik Negeri Padang2

Email:oliyan.fitra@gmail.com

\begin{abstract}
ABSTRAK
Pertumbuhan ekonomi suatu perusahaan merupakan salah satu alat bantu bagi para investor untuk menentukan keputusan dalam berinvestasi. Pada awal tahun 2020 telah terjadi pandemi yang dikenal dengan COVID-19. Dampak dari pandemi ini mulai dirasakan di negara Indonesia pada awal bulan Maret, sehingga terjadi keresahan dalam melaksanakan aktivitas sehari-hari. Adanya kebijakan tentang anjuran bekerja di rumah tidak bisa dilakukan pada setiap sektor industri. Hal ini berimbas pada pekerjaan yang tidak bisa tergantikan dengan work from home. Akhirnya, ada masyarakat yang penghasilannya berkurang dan bahkan hilang. Pemerintah mengeluarkan kebijakan mengenai kelonggaran kredit dalam waktu satu tahun setelah diterbitkannya POJK 11/POJK.03/2020. Peraturan ini merupakan kelonggaran yang diberikan kepada masyarakat yang memiliki kredit kepada pihak financing. Perusahaan dalam sektor keuanganlah yang memiliki dampak langsung atas kebijakan ini. Berdasarkan penelitian yang akan dilakukan akan diketahui apakah pengaruhnya terhadap kinerja keuangan di subsektor lembaga keuangan.
\end{abstract}

Kata kunci: Lembaga Keuangan, Debt to Equity Ratio, Total Assets Turnover, Return on Assets.

\begin{abstract}
The economic growth of a company is one of the tools for investors to make investment decisions. At the beginning of 2020 there was a pandemic known as COVID-19. The impact of this pandemic began to be felt in Indonesia in early March, resulting in unrest in carrying out daily activities. The existence of a policy regarding the recommendation to work at home cannot be implemented in every industrial sector. This has an impact on work that cannot be replaced with work from home. Finally, there are people whose income is reduced and even lost. The government issued a policy regarding credit concessions within one year after the issuance of POJK 11 / POJK.03 / 2020. This regulation is a concession given to people who have credit to financing parties. It is companies in the financial sector that have a direct impact on this policy. Based on the research that will be conducted, it will be known whether the effect on financial performance in the financial institution subsector.
\end{abstract}

Kata kunci: Financial Institution, Debt to Equity Ratio, Total Assets Turnover, Return on Assets.

\section{Pengantar}

Keputusan dalam berinvestasi didasari oleh banyak hal. Investasi bisa menjadi sebuah solusi atas perubahan yang tidak menentu yang akan terjadi di kemudian hari. Para investor bisa mencari beberapa patokan yang bisa menjadi acuan untuk melakukan investasi itu sendiri. Pertumbuhan ekonomi suatu perusahaan merupakan salah satu alat bantu bagi para investor untuk menentukan keputusan dalam berinvestasi.

Jika ingin berinvestasi pada perusahaan tertentu, perusahaan tersebut bisa jadi terkena imbas pada awal pada awal tahun 2020. Di tahun ini telah terjadi pandemi yang dikenal 
dengan COVID-19. Dampak dari pandemi ini mulai dirasakan di negara Indonesia pada awal bulan Maret, sehingga terjadi keresahan dalam melaksanakan aktivitas sehari-hari. Adanya kebijakan tentang anjuran bekerja di rumah tidak bisa dilakukan pada setiap sektor industri. Hal ini berimbas pada pekerjaan yang tidak bisa tergantikan dengan work from home. Akhirnya, ada masyarakat yang penghasilannya berkurang dan bahkan hilang. Pekerjaan yang bukan dari instansi pemerintahan dan tidak mendapat gaji pokok perbulan mendapat imbas dari pandemi ini karena diberlakukannya social distancing yang merupakan kebijakan yang dikeluarkan oleh Presiden Republik Indonesia Joko Widodo.

Social distancing adalah tindakan pembatasan untuk mengendalikan infeksi nonfarmsi atau memperlambat penyebaran suatu penyakit menular (Rizka,2020). Tindakan ini bertujuan mengurangi penyebaran virus dalam masyarakat. Social distancing ini bisa juga disebut dengan physical distancing yang memiliki arti menjaga jarak antara diri sendri dan orang yang berada di luar rumah (NICRD,2020).

Indonesia mengeluarkan aturan untuk pembatasan sosial dengan menerapkan PSBB (Pembatasan Sosial Berskala Besar). Hal ini menyebabkan banyak aktivitas pekerjaan tidak terlaksana dengan semestinya. Kemampuan finansial masyarakat yang tidak memiliki gaji pokok setiap bulan tidak akan mampu memenuhi kewajiban atau tanggungan yang dimilikinya.

Penelitian ini akan melihat dampak dari kebijakan tentang kelonggaran kredit dari peraturan P0JK 11/P0JK.03/2020 karena adanya pembatasan sosial ini. Hal ini dilakukan untuk melihat dampak dari pertaturan tersebut. Oleh karena itu, penelitian ini akan mengambil tanggal penerbitan peraturan tersebut sebagai cut off pembanding saat sebelum dan setelah diterbikannya kebijakan dari pemerintah ini. Sejalan dengan Fitra (2013) didalam penelitiannya mengenai return dengan pendekatan disposition effect memisahkan penilitian menjadi empat periode. Salah satunya adalah saat masa krisis keuangan global pada tahun 2008. Ini menjadi salah satu faktor untuk melihat perbedaan yang terjadi pada periode yang tidak terdapat masalah global yang nantinya akan menjadi penentu para investor untuk mengambil keputusan.

Ada berbagai sebab yang mempengaruhi keputusan investor dalam mengambil keputusan. Akan tetapi, peneliti akan membahas mengenai dampak dari kinerja keuangan. Kinerja keuangan itu sendiri berpangaruh besar terhadap return saham yang nantinya menjadi penentu keputusan investor dalam investasi di pasar modal. Menurut Fitra (2016) kinerja keuangan perusahaan dan faktor makroekonomi mempengaruhi return saham.

Pemerintah mengeluarkan kebijakan mengenai kelonggaran kredit dalam waktu satu tahun setelah diterbitkannya POJK 11/POJK.03/2020. Peraturan ini merupakan kelonggaran yang diberikan kepada masyarakat yang memiliki kredit kepada pihak financing institution. Hal ini merupakan bantuan kepada masyarakat yang keadaan perekonomianya mulai melemah. Apakah masyarakat masih mampu menyisihkan dana yang dimilikinya untuk berinvestasi di financial institution? Perusahaan dalam subsektor lembaga keuangan yang memiliki dampak langsung atas kebijakan ini. Oleh karena itu peneliti memiliki keinginan untuk melihat gambaran atas kinerja keuangan pada subsektor lembaga keuangan.

\section{Analisis Deskriptif Pengembalian Saham Transaksi Rumah Tangga Asing dan dan}

Perusahaan yang terdaftar dalam subsektor financial institution sebelum dan setelah kebijakan POJK 11/POJK.03/2020 
Tabel 1. Nama Perusahaan Subsektor Financial Institution

\begin{tabular}{|r|l|l|}
\hline \multicolumn{1}{|l|}{ No. } & Kode & Nama Perusahaan \\
\hline 1 & ADMF & Adira Dinamika Multi Finance Tbk. \\
\hline 2 & BBLD & Buana Finance Tbk. \\
\hline 3 & BFIN & BFI Finance Indonesia Tbk. \\
\hline 4 & BPFI & Batavia Prosperindo Finance Tbk. \\
\hline 5 & CFIN & Clipan Finance Indonesia Tbk. \\
\hline 6 & DEFI & Danasupra Erapacific Tbk. \\
\hline 7 & FINN & First Indo American Leasing Tbk. \\
\hline 8 & FUJI & Fuji Finance Indonesia Tbk. \\
\hline 9 & HDFA & Radana Bhaskara Finance Tbk. \\
\hline 10 & IBFN & Intan Baruprana Finance Tbk. \\
\hline 11 & IMJS & Indomobil Multi Jasa Tbk. \\
\hline 12 & MFIN & Mandala Multifinance Tbk. \\
\hline 13 & POLA & Pool Advista Finance Tbk. \\
\hline 14 & TIFA & Tifa Finance Tbk. \\
\hline 15 & TRUS & Trust Finance Indonesia Tbk. \\
\hline 16 & VRNA & Verena Multi Finance Tbk. \\
\hline 17 & WOMF & Wahana Ottomitra Multiartha Tbk. \\
\hline
\end{tabular}

Perusahaan tersebut memiliki dampak langsung terhadap peraturan POJK 11/POJK.03/2020 yang telah dikeluarkan. Berikut data mengenai variabel terkait

Tabel 2. Rasio Keuangan Perusahaan Quarter 1 Tahun 2020

\begin{tabular}{|r|l|l|c|c|c|}
\hline \multicolumn{1}{|c|}{ No. } & Kode & \multicolumn{1}{|c|}{ Nama Perusahaan } & D/E Ratio & TATO & ROA \\
\hline 1 & ADMF & Adira Dinamika Multi Finance Tbk. & 3.35 & 0.329607 & 6 \\
\hline 2 & BBLD & Buana Finance Tbk. & 3.27 & 0.120179 & 1.16 \\
\hline 3 & BFIN & BFI Finance Indonesia Tbk. & 2.14 & 0.235618 & 3.73 \\
\hline 4 & BPFI & Batavia Prosperindo Finance Tbk. & 1.22 & 0.16648 & 4.11 \\
\hline 5 & CFIN & Clipan Finance Indonesia Tbk. & 1.58 & 0.178483 & 2.98 \\
\hline 6 & DEFI & Danasupra Erapacific Tbk. & 0.01 & 0.171779 & 16.3 \\
\hline 7 & FINN & First Indo American Leasing Tbk. & 2.78 & 0.101874 & -6.36 \\
\hline 8 & FUJI & Fuji Finance Indonesia Tbk. & 0.01 & 0.083682 & 4.35 \\
\hline 9 & HDFA & Radana Bhaskara Finance Tbk. & 6.13 & 0.192392 & -10.8 \\
\hline 10 & IBFN & Intan Baruprana Finance Tbk. & 3.05 & 0.097935 & 1.05 \\
\hline 11 & IMJS & Indomobil Multi Jasa Tbk. & 1.07 & 0.127338 & 0.47 \\
\hline 12 & MFIN & Mandala Multifinance Tbk. & 0.14 & 0.081206 & -11.3 \\
\hline 13 & POLA & Pool Advista Finance Tbk. & 0.1 & 0.156047 & 2.73 \\
\hline 14 & TIFA & Tifa Finance Tbk. & 2.97 & 126.5946 & 0.07 \\
\hline 15 & TRUS & Trust Finance Indonesia Tbk. & 5.03 & 0.252766 & 3.14 \\
\hline 16 & VRNA & Verena Multi Finance Tbk. & & & \\
\hline 17 & WOMF & Wahana Ottomitra Multiartha Tbk. & &
\end{tabular}


Tabel 3. Rasio Keuangan perusahaan quarter $2-2020$

\begin{tabular}{|r|l|l|c|c|c|}
\hline No. & Kode & Nama Perusahaan & D/E Ratio & TATO & ROA \\
\hline 1 & ADMF & Adira Dinamika Multi Finance Tbk. & 3.66 & 0.081299 & 5.98 \\
\hline 2 & BBLD & Buana Finance Tbk. & 3.2 & 0.0397 & 1.28 \\
\hline 3 & BFIN & BFI Finance Indonesia Tbk. & 2.12 & 0.070935 & 6.66 \\
\hline 4 & BPFI & Batavia Prosperindo Finance Tbk. & 1.18 & 0.091532 & 4.03 \\
\hline 5 & CFIN & Clipan Finance Indonesia Tbk. & 1.48 & 0.180462 & 3.14 \\
\hline 6 & DEFI & Danasupra Erapacific Tbk. & 0.01 & 0.016335 & 2.44 \\
\hline 7 & FINN & First Indo American Leasing Tbk. & 2.78 & 0.1052 & -6.36 \\
\hline 8 & FUJI & Fuji Finance Indonesia Tbk. & 0.01 & 0.017091 & 3.91 \\
\hline 9 & HDFA & Radana Bhaskara Finance Tbk. & 0.96 & 0.035862 & -4.68 \\
\hline 10 & IBFN & Intan Baruprana Finance Tbk. & 4.45 & 0.020305 & 0.39 \\
\hline 11 & IMJS & Indomobil Multi Jasa Tbk. & 7.34 & 0.0464 & 0.36 \\
\hline 12 & MFIN & Mandala Multifinance Tbk. & 0.08 & 0.096018 & 8.71 \\
\hline 13 & POLA & Pool Advista Finance Tbk. & 2.15 & 0.014334 & -4.81 \\
\hline 14 & TIFA & Tifa Finance Tbk. & 0.1 & 0.034138 & 2.24 \\
\hline 15 & TRUS & Trust Finance Indonesia Tbk. & 3.6 & 0.030819 & 2.83 \\
\hline 16 & VRNA & Verena Multi Finance Tbk. & 5.89 & 0.077143 & 2.17 \\
\hline 17 & WOMF & Wahana Ottomitra Multiartha Tbk. & & & \\
\hline
\end{tabular}

Dari data tersebut akan diolah menjadi uji beda, apakah dampak setelah terjadinya POJK 11/POJK.03/2020. Data akan diolah menggunakan uji beda Mann Whitney, hal ini dilakukan karena variabel yang diuji merupakan bentuk skala rasio dan data juga tidak diperlukan dalam keadaan berdistribusi normal namun dalam kemiringan yang sama.

\section{Uji beda Mann Whitney U Test pada quarter satu dan quarter dua}

\section{Debt to Equity Ratio}

Kesamaan bentuk atau penyebaran data terlihat dari Rasio Skewness yang bisa dicari dengan skewness dibagi dengan standar error skewness. Rasio skewness dari rasio Debt to Equity Ratio pada quarter 1 adalah 0.98 dan pada quarter 2 adalah 1.65. Ini menunjukkan bahwa kedua data yang diuji memiliki penyebaran data yang sama.

\section{Hasil uji beda Debt to Equity Ratio}

Tabel 4. Mean DER

\begin{tabular}{|ll|r|r|r|}
\hline & Quarter & \multicolumn{1}{|c|}{ N } & Mean Rank & Sum of Ranks \\
\hline DER & Quarter 1 & 17 & 17.94 & 305.00 \\
& Quarter 2 & 17 & 17.06 & 290.00 \\
& Total & 34 & & \\
\hline
\end{tabular}


Tabel 5. Hasil Uji Beda Mann Whitney DER

\begin{tabular}{|l|r|}
\hline & \multicolumn{1}{|c|}{ DER } \\
\hline Mann-Whitney U & 137.000 \\
Wilcoxon W & 290.000 \\
$Z$ & -.259 \\
Asymp. Sig. (2-tailed) & .796 \\
Exact Sig. [2*(1-tailed Sig.)] & $.812^{\mathrm{a}}$ \\
\hline a. Not corrected for ties. & \\
b. Grouping Variable: Quarter &
\end{tabular}

Dari hasi tersebut bisa dilihat Asymp. Sig (2-tailed) lebih besar dari 0,05. Ini berarti perusahaan yang ada menanggung tingkat hutang yang relatif sama dari quarter 1 dan quarter 2. Perusahaan - perusahaan tidak terdampak akan kebijakan POJK dari segi tingkat hutang.

\section{Total Asset Turn Over}

Hasil dari Rasio Skewness dari periode 1 adalah 7.49 dan periode 2 adalah 2.60. ini menunjukkan bahwa penyebaran data sama ke kanan. Akan tetapi pada periode quarter 1 hasilnya tidak dalam rentang penyebaran yang sama dari quarter 2. Jika ditelusuri lebih lanjut perusahaan Verena Multi Finance Tbk. Mengalami peningkatan pendapatan yang drastis pada quarter 1 . Sehingga data ini bisa mengganggu gambaran perusahaan di bidang financial institution secara keseluruhan. Jika data perusahaan Verena Multi Finance Tbk. Dihilangkan maka akan terlihat maka rasio skewness dari quarter 1 menjadi 2.16 dan pada quarter 2 menjadi 2.38. Ini berarti kemiringan dari quarter 1 dan 2 telah dalam rentang yang sama.

Tabel 6. Mean TATO

\begin{tabular}{|rl|r|r|r|}
\hline \multicolumn{2}{|c|}{ Quarter } & N & Mean Rank & Sum of Ranks \\
\hline TATO & Quarter 1 & 16 & 23.25 & 372.00 \\
& Quarter 2 & 16 & 9.75 & 156.00 \\
& Total & 32 & & \\
\hline
\end{tabular}

Tabel 7. Hasil Uji Beda Mann Whitney TATO

\begin{tabular}{|l|r|}
\hline & \multicolumn{1}{|c|}{ TATO } \\
\hline Mann-Whitney U & 20.000 \\
Wilcoxon W & 156.000 \\
$Z$ & -4.070 \\
Asymp. Sig. (2-tailed) & .000 \\
Exact Sig. [2*(1-tailed Sig.)] & $.000 \mathrm{a}$ \\
a. Not corrected for ties. & \\
b. Grouping Variable: Quarter
\end{tabular}

Hasil dari Asymp. Sig (2-tailed) lebih kecil dari 0.05. ini menunjukkan bahwa hasil pendapatan pada quarter 2 menunjukkan perubahan yang cukup signifikan. Financial institution menerima lebih sedikit dana dari masyarakat untuk dihimpun. Masyarakat mengalami penuruanan kemampuan untuk berinvestasi dalam financial institution. 


\section{Return On Assets}

Hasil dari rasio skewness pada quarter 1 adalah -0.62 dan pada quarter 2 adalah 1.18. hasil penyebaran data untuk ROA ini relatif sama.

Tabel 8. Mean ROA

\begin{tabular}{|ll|r|r|r|}
\hline & Quarter & N & \multicolumn{1}{|c|}{ Mean Rank } & Sum of Ranks \\
\hline ROA & Quarter 1 & 17 & 17.65 & 300.00 \\
& Quarter 2 & 17 & 17.35 & 295.00 \\
& Total & 34 & & \\
\hline
\end{tabular}

Tabel 9. Hasil Uji Beda Mann Whitney ROA

\begin{tabular}{|l|r|}
\hline & \multicolumn{1}{|c|}{ ROA } \\
\hline Mann-Whitney U & 142.000 \\
Wilcoxon W & 295.000 \\
Z & -.086 \\
Asymp. Sig. (2-tailed) & .931 \\
Exact Sig. [2*(1-tailed Sig.)] & $.946^{\mathrm{a}}$ \\
\hline a. Not corrected for ties. & \\
b. Grouping Variable: Quarter
\end{tabular}

Hasil dari Asymp. Sig (2-tailed) lebih besar dari 0.05. Hal ini menunjukkan tidak terdapat perubahan yang signifikan dari quarter 1 dan 2. Perusahaan - perusahaan yang bergerak di bidang financial institution masih mendapatkan laba dan mengaturnya secara efisien dari sumber aset yang dimilikinya.

\section{Kesimpulan}

Penilitian bertujuan untuk mengetahui seberapa besar dampak perkonomian pada masyarakat. Hal yang mendasari penilitan ini adalah adanya kebijakan Peraturan POJK 11/POJK.03/2020. Ini menyebabkan perubahan ekonomi pada masyarakat. Keuangan yang ada pada masyarakat bisa terlihat diantaranya dalam Financial Institution. Financial institution itu sendiri bertugas melakukan penghimpunan dana yang nantinya akan memberikan fasilitas produk di bidang keuangan serta memutar arus uang dalam perekonomian. Hasil dari penilitian ini dapa disimpulkan bahwa:

1. Debt to Equity Ratio, dari segi ini tidak terjadi perubahan yang signifikan. Perusahaan - perusahaan masih memiliki tingkat hutang yang masih sama dari sebelum dan sesudah penerapan kebijakan POJK

2. Total Asset Turn Over, dari segi ini bisa terlihat bahwa terjadi penurunan yang signifikan. Pendapatan Financial institution yang mana bersumber dari dana masyarakat tidak sebanyak sebelum penerapan POJK

3. Return on Assets, dari segi ini financial institution masih bisa mengelola asetnya secara efisien 


\section{Referensi}

[1] Fahmi, Irham. 2011. Analisis Laporan Keuangan. Lampulo: ALFABETA.

[2] Harahap, S. S. .2007. Analisis Krirtis Atas Laporan Keuangan. Jakarta: PT.Raja Grasindo Persada

[3] Jumingan. 2006. Analisis Laporan Keuangan, Cetakan Pertama, PT Bumi Aksara, Jakarta.

[4] Munawir, S. 2012. Analisis Informasi Keuangan, Liberty, Yogyakarta.

[5] NICRD. 2020. "Social Distancing, Quarantine, and Isolation.” Retrieved April 1, 2020 (https://www.cdc.gov/coronavirus/2019-ncov/prevent-getting-sick/socialdistancing.html).

[6] Oliyan, Fitra. 2016. Pengaruh Kinerja Keuangan Perusahaan Dan Faktor Makroekonomi Terhadap Return Saham Perusahaan Yang Terdaftar Di Bursa Efek Indonesia Periode 2010-2014 (Doctoral Dissertation, Universitas Andalas).

[7] Oliyan, Fitra. 2013. Analisa Tingkat Pengembalian Investor Lokal Dan Investor Asing Dengan Menggunakan Pendekatan Disposition Effect (Doctoral Dissertation, Politeknik Negeri Padang).

[8] Rizka. 2020. “Arti Social Distancing Dan Physical Distancing, Apa Bedanya?” Retrieved April 1, 2020 (https://www.indozone.id/life/WYsAgk/perbedaan-socialdistancing-dan-physical-distancing/read-all).

[9] Sutrisno. 2009. Manajemen Keuangan Teori, Konsep dan Aplikasi. Ekonisia, Yogyakarta. 